\title{
Public Knowledge Regarding Coronavirus Disease 19
}

\author{
Tegar Wahyu Priambodo \\ Master of Public Health Program of Public Health Faculty, University Muhamadiyah Jakarta, \\ K.H. Ahmad Dahlan St, Cireundeu, Ciputat South Jakarta, 151419 \\ E-mail: wahyu.tegar@gmail.com
}

\begin{abstract}
Covid-19 outbreak occurred in December 2019 in Wuhan, China, and was named Coronavirus Disease 2019. This Covid-19 phenomenon is a new disease. As time goes on and research continues to be carried out, there are lots of changing facts, that will imply the level of public knowledge about Covid-19 and the public's attitude in dealing with it as its part of mitigating this virus. Thus, it is necessary to research the level of public knowledge regarding Covid-19. The method used in this research is to analyze from various reading sources and references taken are from the national journal. This study took 4 journals as references from the four journals, all of which showed that public knowledge about the Covid-19 phenomenon was good. From the journals that were used as references, information was obtained about the level of public knowledge about the Covid-19 phenomenon in various regions in Indonesia, but further research must be carried out to determine the level of public knowledge about Covid-19
\end{abstract}

Keyword: Covid-19, Knowledge, Public 


\section{INTRODUCTION}

At the end of December 2019, there was an outbreak of a new virus in mainland China, especially in the Wuhan area, which quickly spread in China and outside China, even within 2 months almost the whole world was affected by the outbreak, the symptoms which arise from this outbreak were very similar to pneumonia. After being investigated, the outbreak occurred apparently because of a virus from the corona family, so the World Health Organization (WHO) gave the name, Coronavirus Disease 19, or often called Covid-19. The number 19 was taken from the year the outbreak happened. The rapid and massive spread of the outbreak prompted WHO to declare the Covid-19 outbreak as Global Pandemic. SARS-CoV-2 infection in humans causes symptoms of acute respiratory distress such as fever, cough, and shortness of breath. In severe cases, the disease can cause pneumonia, acute respiratory syndrome, kidney failure, and even death. Symptoms of this disease can appear within 2-14 days after exposure to the virus (Kemenkes RI, 2020). ${ }^{2}$

March $2^{\text {nd }}, 2020$. Indonesia announced its first Covid-19 case in Jakarta and West Java areas. ${ }^{1}$ Confirmed patient for Covid-19 in Indonesia started from an event in Jakarta whereas came in contact with a foreigner from Japan who lives in Malaysia. After the meeting, patients complained of fever, cough, and shortness of breath. ${ }^{3}$ In a short period of less than 1 month, 34 provinces were detected with Covid-19. Therefore, Joko Widodo, President of Indonesia declared the Covid-19 phenomenon as a non-natural national disaster, thus Task Force Gugus Tugas Percepatan Penanganan Covid-19 was formed, which was commanded by Badan Nasional Penanggulangan Bencana (BNPB) at the central level to the regional government in the city and regency areas. ${ }^{1}$

The covid-19 phenomenon, which a new disease, therefore a lot of research carried out massively and continuously. Over time and research that continues to develop, many facts change. Even among researchers, the knowledge regarding Covid-19 is very dynamic, this will have huge implications to the level of public knowledge about the Covid-19 phenomenon. The public is confused about this outbreak, from information about the disease, transmission, severity, how to prevent the disease. The government must provide information about Covid-19 so that people can independently prevent the disease in their surroundings. ${ }^{4}$ The Government has its instruments through the ministry of health at the national level and the health office at the regional level, both at the provincial and district or city levels. The instrument also added with a task force which placed on national level led by BNPB and at the regional level led by their respective head region. These were excellent for facilitating communication and coordination between the central government and local governments. This study aims to determine the level of knowledge of the Indonesians about Covid-19 from various regions. 


\section{METHODS}

The method used in this research is to analyze from various reading sources. This research is a literature study. Researchers refer to several kinds of literature and journals published online, published in 2020 to 2021 . The analysis was carried out by comparative analysis.

RESULTS

\section{AND}

DISCUSSION

This study took 4 journals as references. The journals taken as reference are:

Table 1: Journal as References

\begin{tabular}{ccccc}
\hline \multirow{2}{*}{ No } & \multirow{2}{*}{ Journal } & \multicolumn{3}{c}{ Knowledge about Covid-19 } \\
\cline { 3 - 5 } & & Good & Fair & Poor \\
\hline 1. & First Journal & $72 \%$ & $26 \%$ & $2 \%$ \\
\hline 2. & Second Journal & $53,6 \%$ & - & $46,4 \%$ \\
\hline 3. & Third Journal & $70 \%$ & & $30 \%$ \\
\hline 4. & Fourth Journal & $90 \%$ & $10 \%$ & - \\
\hline
\end{tabular}

The four selected journals were conducted on the island of Java in 2020, all selected journals showed that the level of public knowledge about Covid-19 was quite good. ${ }^{5,6,7,8}$

The first journal, with the title Description of Pekalongan Society Knowledge About Covid19, was conducted by Izzatun Nidaa from UPTD Siwalan Health Centre, Pekalongan Regency. This research was published in the Pekalongan City Research and Development Journal in 2020. This research itself was carried out during 7-10 June 2020 using an online questionnaire, namely Google Form. Respondents obtained were 122 people with 30 male respondents, 92 female respondents, the majority of respondents were aged 17-45 years and the majority level of respondent education was bachelor level. Respondents came from Pekalongan City and Pekalongan Regency, Central Java, the distribution of 71 respondents is from Pekalongan City and 51 respondents from Pekalongan Regency. The questions asked about the causes of Covid-19, the symptoms caused, transmission, prevention, groups at risk, cough/ sneezing etiquette, swab tests, and others. ${ }^{5}$ The results of this study indicate that $72 \%$ of respondents have good knowledge, $26 \%$ of respondents have a fair knowledge and $2 \%$ of respondents have poor knowledge.

The second journal with the title Description of Knowledge, Attitudes, and Public Anxiety Levels about the Covid-19 in the Taman Banten Lestari Housing Environment Serang City in 2020, conducted by Ghina Salsa Bela, Lenny Stia Pusporini, Nila Warwiyah, and Bambang Kuntarto from Falatehan University, Serang, Banten Province. The research was published in the Falatehan Health Journal in 2021. This research was conducted with 84 respondents, namely people who live in the Taman Banten Lestari Housing Complex, RW 21. This research was conducted on May 18, 2020, using an online questionnaire, namely Google Form. Some examples of questions regarding the level of public knowledge of Covid-19 in this study are How long does it take from being infected/infected 
until symptoms of the Covid-19 infection appear? Who is at high risk of being infected with the Covid-19 virus? There is currently no effective drug for Covid-2019, but early symptomatic and supportive treatment can help most patients recover from infection? How many steps are there in good and correct handwashing? and others. The results of this study indicate $53.6 \%$ of respondents have good knowledge, while $46.4 \%$ of respondents have poor knowledge. ${ }^{6}$

The third journal, with the title Overview of Public Knowledge About Covid-19 and Public Behaviour During the Covid-19 Pandemic, was researched by Ni Putu Emy Darma Yanti, I Made Arie Dharma Putra Nugraha, Gede Adi Wisnawa, Ni Putu Dian Agustina, and Ni Putu Arsita Diantari from Faculty Medicine and The Faculty of Mathematics and Natural Sciences, Udayana University Bali. This research was published in the Journal of Mental Nursing in August 2020. This research was conducted on 150 people in Sumerta Kelod Village, Denpasar, Bali. Male respondents amounted to $55.33 \%$ and female respondents amounted to $44.67 \%$. The majority of respondents with a bachelor's degree are $52.67 \%$, aged between $17-25$ years (34\%), and have a job as a private employee or private retiree $(30.67 \%)$. This research was conducted using an online questionnaire, namely Google Form. Some examples of questions regarding the level of public knowledge of Covid-19 in this study are that Covid-19 is a harmless disease and just like the common cold, the coronavirus can survive several hours outside the human body, only people who can transmit Covid-19 can survive. have symptoms, the symptoms of Covid-19 in the elderly are generally more severe than at a young age and others. The results of this study indicate that $70 \%$ of respondents have good knowledge, while $30 \%$ of respondents have poor knowledge. ${ }^{7}$

The fourth journal, with Level of Knowledge and Behavior of the People of Wonosobo Regency About Covid-19, was carried out by Ika Purnamasari and Anisa Ell Raharyani, who are nursing lecturers at FIKES UNSIQ Wonosobo. This research was published in the Scientific Journal of Health in 2020. This research was conducted with 144 respondents from the people of the Wonosobo Regency. This research was conducted for 1 week using an online questionnaire (Google Form) which was distributed through the Whatsapp application. The questionnaire consists of 20 questions for the knowledge questionnaire. The knowledge variable is measured and categorized ordinal, namely the knowledge of the people of Wonosobo Regency is categorized into three levels, Good (if the respondent's score is 76-100), Fair (56-75), and Poor (if <56). Based on all the characteristics of the respondents, information was obtained that most of the respondents were in the productive age (26-45 years) and most of the respondents were female. Most respondents' education level is Diploma and S1 and the respondent's occupation is a private employee. The results showed that the knowledge of the people of Wonosobo Regency about Covid-19 was in a Good category $(90 \%)$ and only $10 \%$ was in the fair category. ${ }^{8}$ 


\section{CONCLUSIONS AND SUGGESTIONS}

From the journals studied, information was obtained about the level of public knowledge about the Covid-19 phenomenon. From the four journals obtained, all of these journals show that people in Indonesia already have enough good knowledge about Covid-19, especially people on the islands of Java and Bali. This is because three studies were conducted in the Java Island Region, Pekalongan, Wonosobo (Central Java Province), and Serang City (Banten Province) one study in Bali, precisely in the Denpasar Region. All research was carried out in 2020 so that it shows that people have quickly gained the right knowledge about Covid-19. However, if it is seen from the increasing number of cases that continue to increase and the level of public compliance with health protocols is still low, research must be carried out on public behavior towards the Covid-19 phenomenon and its relationship with the level of public knowledge. In addition, research on the level of public knowledge must also be carried out more broadly to get more valid results.

\section{REFERENCES}

1. Amtha Rahmi, Gunardi Indra, Dewanto Iwan, Widyarman Armelia Sari, Theodora Citra. Panduan Dokter Gigi Dalam Era New Normal. Satgas Covid-19 Pengurus Besar Persatuan Dokter Gigi Indonesia. 2020 Juli:1

2. Syakurah Rizma Adlia, Moudy Jesica. Pengetahuan terkait Usaha Pencegahan Coronavirus Disease (COVID-19) di Indonesia. Higeia Journal of Public Health Reaserch and Development. 2020 Juli:4(3)

3. Yuliana. Corona Virus Disease (Covid-19); Sebuah Tinjauan Literatur. Welness and Health Magazine. 2020 Feb:2(1);187-192

4. Handayani Diah, Hadi Dwi Rendra, Isbaniah Fathiyah, Burhan Erlina, Agustin Heidy. Penyakit Virus Corona 2019. Jurnal Respir Indo. 2020 April:20(2)

5. Nidaa Izzatun. Gambaran Pengetahuan Masyarakat Pekalongan Tentang Covid-19. Jurnal Litbang Kota Pekalongan Vol 19. 2020

6. Ghina Salsa Bela, Lenny Stia Pusporini, Nila Marwiyah dan Bambang Kuntarto. Gambaran Pengetahuan, Sikap, dan Tingkat Kecemasan Masyarakat tentang Kejadian Covid-19 di Lingkungan Perumahan Taman Banten Lestari Kota Serang Tahun 2020. Faletehan Health Journal 8(1) (2021) 42-50.

7. Ni Putu Emy Darma Yanti, I Made Arie Dharma Putra Nugraha, Gede Adi Wisnawa, Ni Putu Dian Agustina, Ni Putu Arsita Diantari. Gambaran Pengetahuan Masyarakat Tentang Covid-19 dan Perilaku Masyarakat Di Masa Pandemi Covid-19. Jurnal Keperawatan Jiwa Volume 8 No 3, Agustus 2020 , Hal 485 
8. Ika Purnamasari, Anisa Ell Raharyani. Tingkat Pengetahuan dan Perilaku Masyarakat Kabupaten Wonosobo Tentang Covid-19. Jurnal Ilmiah Kesehatan 2020 